\title{
THE REPRESENTATION OF BRUNEI'S SHARIA LAW IN NEW STRAIT TIMES AND BANGKOK POST
}

\section{Luluk Kholidatul Oktavia [1], Sahiruddin [2], Ismatul Khasanah [3]}

\author{
[1] lulukkoktavia@gmail.com, [2] shrdn@ub.ac.id, [3]ismatulkh@ub.ac.id \\ Universitas Brawijaya \\ Malang, Jawa Timur, Indonesia
}

\begin{abstract}
The purpose of this study is to discover positive-self and negative-other representations of Brunei's Sharia Law on LGBT through the lexical choices used by the New Strait Times and Bangkok Post also reveals the ideology from both of the media. This study uses a qualitative approach with critical discourse analysis as the research design. Following Van Dijk's analytical framework, the words were selected and classified into word class, type of meaning (lexical or contextual), and category (positive or negative). Ideology from both media is obtained from the cognition analysis of the journalist's expression based on the co-text, context, and social context (social condition). The result showed that both media used lexical choices that indicate positive representation of LGBT by stating LGBT as victims, while negative representation on Brunei's Government, Muslim, and Sharia law as a persecutor. There were four methods in indicating the positive representation of LGBT; noun/noun phrase representation, detailed information on a noun, verb indicating accusation, and verb indicating discrimination; also there were three methods used to indicate negative representation of Brunei's Government, Muslim, and Sharia law; noun/ noun phrase representation, verb indicating negative actions, and verb indicating provocations.
\end{abstract}

Keywords: Brunei's Sharia Law, lexical choice, positive-self, negative-other

\section{INTRODUCTION}

A social problem is a condition or situation where particular society members are reputed as a threat since being considered to have abused the existed norms and values (Fuller \& Myers, 2003). Besides, Nisbet (1971) claim that social problem emerges when a sizeable difference occurs between a society's ideals and its actual achievement. By such description, it is seen that social problem emerges and occurs when the common norms or values of a particular society are abused by another society where they are seen as a treat by the mainstream or majority society. In other words, such abuse leads to be the central point of social problems conducted by those who might not feel comfortable by the norms (commonly shaped by religion) that bind the process of lives. Moreover, it is then divided reasonably into the majority society and those of minority society.

Accordingly, based on such circumstances, Wang et al. (2016) stated that such society's classification (majority and minority) leads to the treatment by how those who dominate (the majority) treat the minority, moreover the sexual orientation (for example, LGBT). The minority who abuses is defined as the "other" group, which gets the misinterpretations from generation to generation. Theoretically, ethnic/cultural majorities and minorities (social framing) represent social problems where lead to how ideological effect occurs. This study's primary interest is where the social framing influences the ideology, but this study does not look at those two aspects of framing (majorities and minorities) but only looks at the representative of minorities. 
Friedman et al. (2011) found that the most abuse for a minority group is sexual abuse, in which LGBT tend to have social abuse more than racial minorities like color and religion. More than 76 countries' laws still criminalize sex relationships between adults, exposing an individual to the risk of arbitrary arrest, prosecution, the imprisonment-even death penalty. These discriminatory laws perpetuate stigma and discrimination and hate crime, police abuse, torture and ill-treatment, family and community violence, and negatively affect the LGBT people. Moreover, a public survey conducted in 39 countries investigating the numbers of acceptance on LGBT people in the world reveal thatLGBT is accepted in North America, the European Union, and Latin American, but it is refused in the Middle East, African, and some countries in Asia (Pew Research Center, 2013). The survey also found that the acceptance and refusal of LGBT are based on the religion in the country, in which the countries who accepted the LGBT is a country where religion is not a center in people's lives like the US, Britain, Spain, France, Germany, and Japan. At the same time, the countries that refused LGBT are countries where religion is a center of people's lives, like Algeria, South Sudan, Afghanistan, United Arab Emirates, Iran, Brunei Darussalam, Malaysia, and Indonesia (Global Attitude Survey, as cited in Pew Research Center, 2013).

In this sense, the acceptance and refusal of LGBT still become a debatable case around the world. Moreover, Brunei's Sultan called for Islamic teachings to strengthen new Sharia punishments, including death by stoning for gay, sex, and adultery on April3, 2019. Thenew laws made Liwat $^{1}$ punishable in certain circumstances with death by stoning or whipping and imprisonment, while Mushabaqqah ${ }^{2}$ punishable with a fine up to $\mathrm{B} \$ 4,000$, imprisonment for up to ten years, whipping not exceeding 40 strokes, or a combination of any two of these.

As a country with Islamic law, the LGBT case in Brunei is not a new thing. Since 2011 Brunei described as a country with the most worrisome state of rights for LGBT people in South East Asia (New York Times, 2019), a study made by Outright International only found 29 LGBT respondents, with some of them were foreigners. Those studies illustrated how LGBT people in Brunei choose to remain silent and discreet about their sexual orientation. Another study conducted by the United States Department in 2017 also found that sexual orientation and gender identity of LGBT people made them receive acts of violence, discrimination, and other abuses.

As the Sultan forces the Sharia Law on LGBT, it sparks alarm around the world with some countries support it, but almost all of them oppose the policy. As a country that used Sharia Law, Saudi Arabia agrees with this law, but Britain, Australia, America, New Zealand, and The United Nations High Commissioners for Human Rightslabeling this law as Cruel and Inhumane (New York Times, 2019). Some wellknown figures also have lined up to add their name to make a protest about this law, including former U.S. vice president Joe Biden. In the protest, Biden (2019) stated that the code was barbaric to the core, imposing archaic punishments for acts that should not be even crimes. They also called to boycott nine Bruneiowned hotels in Europe and the United States and call the world to support the LGBT in Brunei.

As a law that made huge pros and cons, this law became a headline in every media. Two media that made a headline about this law were the New Strait Times and Bangkok Post. New Strait Times is one of the Malaysian newspapers that aims to supply the best journalism product with relevant and attractive material. At the same time, Bangkok Post is one newspaper from Thailand which legalizes LGBT. As a newspaper in a country where media censorship is common, Bangkok Post provides accurate and trustworthy information. At the same time, New Strait Times wrote news with the title "Exodus by Brunei's LGBT Community ahead of New Sharia Law," while Bangkok Post wrote, "Sharia Law Plunges Brunei Gay Community into Fear." That two news becomes interesting to analyze because both of them talked about Brunei's Sharia Law in LGBT, but they have a different point of view as Bernestei \& Leeuwen (1993) state that news is not an objective representation of fact, but it is a report or recontextualization of the event.

The different titles from the event also indicate that both mediaare very ideological in reporting the event as Tamburaka (2016) stated that all media contents are constructed for a particular purpose with their ideological 
beliefs to influence people's belief in perceiving the information. Furthermore, media bring their ideology and power to influence society; using framing from Gamson and Modiglami, she analyzes the framing of Homosexual in two newspaper in Indonesia, namely Tempo.co and Republika. She found that both of the media influence society to make a negative framing of homosexual people. Homosexuals become "Other" because they are framed as different, terrific, tend to do violence, and have to keep away from society because they are against the religion. Similarly, Maharani (2018) also found that heteronormative discourse links with religious conservatism to influence the society to emphasize the sexual minorities (LGBT) as the subject of Folk Devils and the Other. Another study conducting by Khan, et al (2019) also found that LGBT people tend to stigmatize and marginalized in their society, they tend to be confronted daily by social and institutional discrimination, and little is known about the challenges and concerns facing them.

Some of the studies proved the evidence that news linked to the question of how participants are recontextualized. In the previous case, LGBT people as the minority group recontextualized negative as "Other" while the majority group recontextualized positive as "Self." This case contrasts with Cook's (2018) study focusing on the representation of LGBT from 2001 in American discourse. The result showed that the representation of bisexual and transgender characters has increased since 2001. LGBT characters are portrayed as more affectionate than was seen in 2001; also, the society portrayed LGBT people more positively. Another study conducted by Reynold (2019) also found that LGBT people tend to be open in society.

Hence, LGBT is not only recontextualized as negative-other but also positive-self. It supports Fowler's (1991) idea that the press's world is not the real world but skewed and judged. It means that there is a specific reproduction of media discourse before it is being published for society. As a detailed reproduction of media, the concept of news is ambiguous. It implies that in one place, the news will display some new information to the general public, but in another place, the news information is passed objectively from the outside point of view, because there are many parties take in part like journalist, reporters, editors, sub-editors, and all of them have their ideology.

Moreover, news involves substitution, deletion, and addition of elements from the social parties. It is in line with the representation of LGBT as the minority-group and Brunei as the majority group, which represents it differently in the media. Seen from the gap that some media tend to represent LGBT negatively (Maharani, 2018; Khan et al, 2019) while the others tend to represent LGBT positively (Cook, 2018; Reynold, 2019), this study delivered to discover the positive-self and negative-other representation both minority and majority as self and other. Thus, this objective of the study is delivered to discover the positive-self and negative-other representation of Brunei's Sharia Law on LGBT depicted through the lexical or word choices used by New Strait Times and Bangkok Post also reveal the id eol ogy from both of the media in line with the positive-self and negative-other representation.

\section{METHOD}

This study used a qualitative approach with Critical Discourse Analysis as the research design. In a discourse study, it should be noted that discourse analysts are not mainly concerned with the sample size of its defined corpus because a large sample can create an unmanageable amount of data without adding the analytical outcome of the study. Therefore, useful analytical interpretation in discourse study can also be made with a small sample size of the corpus (Walkar, 2018). According to Baker (2006), we are always more specific to choose the extracts from any speech, interview, or statement based on keywords in discourse study. He further added that the focus should be on the quality of the data during the data collection, not quantity. Thus in this study, the study focused on words, phrases, and sentences of Brunei's Sharia Law from the New Strait Times entitled "Exodus by Brunei's LGBT Community ahead of Sharia Law" and Bangkok Post entitled "Sharia Law Plunges Brunei Gay Community into Fear." Those two articles become essential to analyze because they talked about Brunei's Sharia Law in LGBT. However, they have a different point of views as Matila (2013) stated that news not only 
conveys the crucial information that newsreaders should know, but it also forms ideologies, ideas, or beliefs about states of affairs and different groups of individuals, and one of whom are LGBT case that often mentioned in the news. Thus, the different title from a similar event indicates that both media are very ideological in reporting the events.

Following Van Dijk's (1995) Critical Discourse Analysis, this study exposes Brunei's Sharia Law texts' ideological representation through language. It comprised two types of analysis levels, namely micro and macro analysis. In the microanalysis, the lexical choices are constructed. In constructing any level of sentence structure, choices are made, thus implying that there are choices, and in turn, this implies that there is the reason for making particular choices rather than others as Fowler (1991) views lexis as a vital part of the reproduction of ideologies in the news article because it can be seen as a reflection of culture. Moreover, Dijk (2001) also mentioned that lexical choices convey beliefs and influence of the recipient's opinions and attitudes. Therefore, in implying the text's microanalysis, lexical choices, the words containing the expression related to the representation of Brunei's Sharia Law on LGBT are selected and classified. In the macro analysis, these results were discussed with the social context to uncover two newspaper companies' ideology in depicting the positive-self and negativeother representation of Brunei's Sharia Law.

\section{FINDING AND DISCUSSIONS}

This study reveals the representation of Brunei's Sharia Law in the New Strait Times and Bangkok Post in both complex and multidimensional by having positive and negative representation from the use of lexical choices. Thus, there is the recontextualization of an event that reflects the news ideology in those news articles. According to Leeuwen (1996), the way an event is recontextualized in the news is always linked to the linguistic classificatory system. Thus, the recontextualization can have a positive or negative impact depending on the given objective.

\section{Positive Representation from New Strait Times and Bangkok Post}

The result showed four methods used to positively construct the representation of LGBT from the New Strait Times and Bangkok Post. The expressions are identity noun/ noun phrase representation, detailed information on a noun, verb indicating accusation, and verb indicating discrimination. The number of positive expressions from the two articles can be seen in the chart bellow.

Table 1. Positive Representation of New Strait Times and Bangkok Post

\begin{tabular}{lc}
\hline Classification & Total \\
\hline $\begin{array}{l}\text { Identity noun/ noun } \\
\text { phrase representation }\end{array}$ & 5 \\
\hline $\begin{array}{l}\text { Detailed information on } \\
\text { noun }\end{array}$ & 3 \\
\hline $\begin{array}{l}\text { Verb indicating } \\
\text { accusation }\end{array}$ & 3 \\
\hline $\begin{array}{l}\text { Verb indicating } \\
\text { discrimination }\end{array}$ & 11 \\
\hline
\end{tabular}

The table above shows that the verb indicating discrimination has the highest point than the other aspects, while the detailed information on nouns and verbs, indicating accusation, has the lowest point in the positive representation of LGBT. Based on the previous charts, the four aspects that reflect the positive representation of LGBT in the New Strait Times and Bangkok Post will be further explained below.

1.1 Identity noun/ noun phraserepresentation Identity noun/ noun phrase representation classification signifies the detailed information about the social actor like age, gender, social class, and physical appearance mentioned in the articles. The examples of the identity noun/ noun phrase representation can be found in the following analysis.

\section{Sentence 1}

"The 19-year-old woman namely Zoe, who was born male but identified as female from early childhood, is now awaiting the outcome of her asylum application in Canada after fleeing her country late last year" (New Strait Times, paragraph 2)

\section{Sentence 2}

"Bandar Seri Begawan, Brunei Transgender woman Zoella Zayce fled her native Brunei last year as the country shifted towards hard line Islam, and thinks more of LGBT community will follow after the death penalty 
for gay sex was introduced" (Bangkok Post, paragraph 1)

The above examples show that The New Strait Times and Bangkok Post almost the same in mentioning the identity noun/ noun phrase representation. In the New Strait Times, the journalist attaches additional information about the actor, the name and gender, age, and physical appearance. Similarly, although Bangkok Post did not mention the actor's age, it also clearly mentions the actor's name (in bold format), gender, and physical appearance.

Based on the above citation, the journalist recontextualized the social actor by attaching the additional information that stated the social actor's age, gender, and physical appearance. According to Bednarek (2016), telling someone's detailed information includes someone's age, gender, and appearance in a news article, is considered one of the personal identifiers to provide a more accurate report. Besides, mentioning someone's age, gender, and physical appearance in the news can raise the context of meaning delivered in the article and emphasize the actor's importance in the context.

1.2 Detailed information on noun

To develop a positive representation of LGBT, Bangkok Post provide complete and detailed information on a noun. The examples of detailed information on noun can be found in the following analysis

\section{Sentence 1}

"The LGBT communitytend to keep a low profile and LGBT (people) are generally much less open than in some of Brunei's neighbours, such as Thailand." (Bangkok Post, paragraph 14)

According to the Cambridge online dictionary, the word "Low profile" has a synonym with "Keep quiet." It refers to a position of avoiding or not attracting much attention or publicity. "Low profile" indicates the positive of LGBT.

\subsection{Verb indicating accusation}

The verb phrase that indicates accusation as information means that the media's information is treated as an accusation to a social actor by adding someone else's statement or thoughts (Betari et al. 2020). In this classification, the journalist used the verb, indicating accusation to develop a positive representation of LGBT. The examples of the verb indicating accusation can be found in the following analysis.

\section{Sentence 1}

"The laws license for other people to see the LGBT people as criminals, commit violence and abuse towards them" (New Strait Times, paragraph 5)

According to the Cambridge online dictionary, the verb "Criminals' "Commit Violence," and "Abuse" have the synonym as "Law Breaker." Those three verbs indicate that LGBT is evil, dangerous, and morally wrong because they break the law. These statements indicate as the causation that LGBT is someone who does terrible and breaks the law.

\subsection{Verb indicating discrimination}

Verb indicating discrimination signifies the distinction against a person based on the group, class, or category to which the person belongs (Betari et al., 2020). In this classification, the journalist used the verb, indicating discrimination to develop a positive representation of LGBT. The example of a verb indicating discrimination can be found in the following example.

\section{Sentence 1}

"Even before Sharia law, LGBT people could be prosecuted under civil law" (New Strait Times, paragraph 3)

According to the Cambridge online dictionary, the verb "Prosecuted" semantically means "accused." Using "Prosecuted" implies that LGBT is discriminated against even before the sharia law because they accused the legal institutions proceeding against the country.

\section{Sentence 2}

"Muslims who want Sharia Law just keep it with themselves and God. Not enforce it on to the other people" (New Strait Times, paragraph 18)

According to the Cambridge online dictionary, the verb "Enforce" semantically means "impose." Using "Enforce" implies that LGBT is acceptable, but then implies the discrimination for the Muslim community who force those laws. In this context, "Enforce" means discrimination for LGBT people to obey the Muslim law or make a sharia law accepted by LGBT.

\section{Negative Representation from New Strait Times and Bangkok Post}


Aside from the positive representation from both media, negative words are still used to label the other's actor. In this study, there are three methods used to negatively construct the representation of Brunei's Government, Muslim and Strict Law. They are noun/ noun phrase representation, verbs indicating negative actions, and verbs indicating provocations. The number of negative expressions from the New Strait Times and Bangkok Post can be seen in the chart bellow.

Table 2. Negative Representation from New Strait Times and Bangkok Post

\begin{tabular}{lc}
\hline Classification & Total \\
\hline $\begin{array}{l}\text { Noun/ noun phrase } \\
\text { representation }\end{array}$ & 6 \\
\hline $\begin{array}{l}\text { Verb indicating } \\
\text { negative actions }\end{array}$ & 6 \\
\hline $\begin{array}{l}\text { Verb indicating } \\
\text { provocations }\end{array}$ & 3 \\
\hline
\end{tabular}

The table above shows that the noun/ noun phrase representations and verb indicating negative actions have the highest point the negative representation from the New Strait Times and Bangkok Post, while verb indicating provocations has the lowest point than the other aspects. Based on the previous chart, the threeaspects that reflect the negative representation of Brunei's Government, Muslim and Strict Law will be further explained below.

2.1 Noun / noun phrase representation

Noun/ noun phrase representation classification signifies the detailed information about the noun that consists of additional information about the country and Muslims. To develop a negative representation of Brunei's Government, Muslim, and the law, both the New Strait Times and Bangkok Post provided detailed information about the country and Muslim as seen in the following example

\section{Sentence 1}

"Brunei, a Muslim-majority former British protectorate with a population about 400.000 is due to implement Sharia Laws from April 3, punishing sodomy, adultery and rape with the death penalty, and theft amputation."

\section{Sentence 2}

"The absolute monarchy on tropical Borneo Island, ruled by a sultan who has been on the throne five decades, implemented through new Islamic Laws on Wednesday, including death by stoning for sex between men and adultery."

In the above examples, it is seen that the New Strait Times and Bangkok Post have a different way of mentioning the noun/ noun phrase representation. In the New Strait Times, the journalist attaches additional information about the country like location, a brief history of the country, and the people in those countries. Simultaneously, the Bangkok Post used "Absolute monarchy" to describe the country and make labeling for Brunei's government because they intensely disliked the LGBT.

2.2 Verb indicating negative actions

The journalists used verbs indicating negative actions to develop the negative representation of Brunei's Government, Muslims, and the law. The examples of the verb indicating negative actions can be found in the following analysis

\section{Sentence 1}

"Brunei's decision contravenes several International norms on human rights," New Zealand's Foreign Minister Winston Peters said in a statement on Sunday" (New Strait Times, paragraph 20)

According to the Cambridge online dictionary, "Contravenes" semantically means "violate." The word "Contravenes" here clearly stated a negative evaluation of Brunei. With those words, Brunei is seen as a country that violates human rights using Sharia Law.

\section{Sentence 2}

"What Brunei is adopting is a violation of human rights" a 33-year-old gay man in the country, who spoke anonymously" (Bangkok Post, paragraph 4)

Again, the word "Violation" is used in this news; here, the word "Violation" clearly stated Brunei's negative evaluation. If in the first sentence, the word came from New Zealand Prime Minister, this word came from the participant. The contextual meaning also said that Brunei is seen as a country that violates human rights.

\section{Sentence 3}

"Khairul, a gay man in Brunei who gave onlyone name, described the laws as "daunting," adding: When I'm ready, I'll be on my way to a safer community."

According to the Cambridge online dictionary, "Daunting" semantically means "intimidating." The word "Daunting" clearly 
stated the negative evaluation of the government's law. With those words, Sharia Law is seen as intimidating law for LGBT people.

From the above lexical choices, both the New Strait Times and Bangkok Post give Brunei and Brunei's government information as a country that violates and intimidates human rights. Here, the media led the reader's opinion by bringing up charges of Brunei's violation. This particular case of negativity in line with the criteria of negative news stated by Harcup and O'neill (2001) to grab the reader's attention, the media puts a heavy emphasis on the long-running selected crimes.

2.3 Verb indicating provocations

This classification indicates a provocation through the selection of verb or verb phrase in which the chosen words will build a negative representation of Brunei's Government, Muslim, and the law. The examples of the verb indicating provocations can be found in the following analysis

\section{Sentence 1}

"The laws licence for other people to see LGBT people as criminals, commit violence, and abuse towards them" (New Strait Times, paragraph 5)

According to the Cambridge online dictionary, "Licence" semantically means "allowed." The word "Licence" here clearly stated the negative evaluation of Brunei's Government because the result of those licenses makes a negative framing for LGBT. They are framed as criminals, commit violence, and abuse.

The result describes that the representation of Brunei's Sharia Law in news media is not equal and neutral. In line with Nurhayati (2014), the media report is not always objective, butindividuals or institutions construct and construe the fact. Moreover, the media's information is limited because it is selected based on their point of view and stance (Muqoffa, 2020). Thus, it is also necessary to determine the motives of media using their power abuse to frame the Ingroup's role. New Strait Times and Bangkok Post are two-well known English-language in the Eastern Press. New Strait Times is an English-language newspaper published in Malaysia. The name was changed in 1974. This newspaper followed the British newspaper like The Times and The Independent. In reporting the politics and social issues, the New Strait Times tends to be competent and attractive; this case made the New Strait Times banned in Singapore in 1969. Based on those case, New Strait Times tend to owe the politically sensitive, like Brunei's Sharia Law of LGBT while Bangkok Post is a broadsheet Englishlanguage daily newspaper published in Bangkok, Thailand. In Thailand, where media censorship is common, Bangkok Post portrays them as being comparatively free. Based on those facts, it can be said that the New Strait Times and Bangkok Post tend to interest in the political issue, and the readers of the newspaper were predominantly International people. In other words, the New Strait Times and Bangkok Post support LGBT rather than Brunei's Government because of their beliefs. Therefore, the media are demanded to report news based on the reader's belief. According to Fowler (1991), this kind of social relations is one factor that determines the output and activities of media. They prefer to report the positive representation of LGBT and negative representation of Brunei's Government, Muslims, and the Law.

Besides, this representation is also influenced by religious heterogeneity as the underlying factors that influence the positive and negative representation of Brunei's Sharia Law. Religion can promote a variety of prosocial beliefs and norms for a community. However, religious diversity does not requirea shared set of values and standards to be conveyed to the community members (Moore, 2015). Religious heterogeneity makes people left unaware of many different norms and beliefs. Durkheim (1951, as cited in Moore (2015) suggested that religion's real power was its capacity to integrate people into society and regulate their understanding. Moore (2015) also stated that the values and beliefs would be apparent to society when there is one dominant religion. Thus, people would be clear about what beliefs are appropriate because religion would regulate them well. Since religious heterogeneity will be producing different values and standards, individuals would, therefore, not have a clear understanding of the right behaviors and beliefs.

The representation of Brunei's Sharia Law might be raised because of the lack of understanding about the "other" religion. 
Again, it happens not only for people but also the journalists. The misunderstanding from a journalist can gain misinterpretation that will have a massive influence on people's thoughts. For instance, the New Strait Times and Bangkok Post articles did not show a clear statement or interview with the social actor concerning the damaging accusations. Both of the media did not ask Brunei's government directly for a confirmation, but they provided information from the LGBT side and secondhand information such as quotes from other media and sources in their articles. Thus, it causes a high potential of misconception toward Brunei's Government, Muslims, and the law. The unavailability of balanced information triggers misunderstanding for readers and journalists; it is because the heterogeneity brings a differentiation of the value, behaviors, and beliefs. The concept of homophily in social psychology indicates that people are more likely to trust those close to themselves in one way or another. It means that people are more likely to meet similar others in religiously homogeneous countries and are therefore more willing to trust them (Olson $\& \mathrm{Li}, 2015$ ). Also, the degree of mistrust can change over time. As mentioned above, religion is one of the most obvious reasons people are separated, distanced, or even antagonized.

\section{CONCLUSION}

The present study provides a Critical Discourse Analysis of the New Strait Times and Bangkok Post in reporting Brunei's Sharia Law on LGBT. By integrating Vand Dijk's (1995) analytical framework, the results reveal that both media portray LGBT as Self-group that refers to LGBT as victims and good fighters in contrast to Other-group that belongs to Brunei's Government, Muslim and Sharia Law as a persecutor. The verbal analysis in lexical choices used by the New Strait Times and Bangkok Post demonstrated the writers' ideological positions, indicating the strategy of positive-self representation and negativeother representation. It can be concluded that these discursive practices are influenced by social relations and religious heterogeneity that portray the ideological landscape of the media. Therefore, this study aims to raise the readers' awareness that what they read andsee is not the real event but the recontextualization of the event; thus, the readers are hoped to read critically to get reliable information. Moreover, it has to be acknowledged that this study's data are limited, and it is interesting to continue this study in the case of Brunei's Sharia law. The next researchers could conduct a further study using more various media from the other countries and by implementing another framework, such as multimodal analysis.

\section{REFERENCES}

Bednarek, M. (2016). Voices and values in the news: News media talk, news values and attribution. Discourse, Context \& Media, 11, 27-37.

Bernestei, \& Leeuwen, V. (1993). Language and Representation: The Rrecontextualization of Participants, Activity and Reactions. University of Sydney.

Betari, A. W., Tabiati, S. E., \& Sahiruddin, S. (2020). The Representation of Zakir Naik in "Al Jazeera” and "the Independent." Jurnal Kata, 4(1), 109.

Cook, C. (2018). A content analysis of LGBT representation on broadcast and streaming television. Student Reserch, Creative Works, and Publications, 48.

Fowler, R. (1991). Language in the News: Discourse and Ideology in the Press. Routledge.

Friedman, M. S., Marshal, M. P., Guadamuz, T. E., Wei, C., Wong, C. F., Saewyc, E. M., \& Stall, R. (2011). A meta-analysis of disparities in childhood sexual abuse, parental physical abuse, and peer victimization among sexual minority and sexual nonminority individuals. American journal of public health, 101(8), 1481-1494. 
Fuller, R. C., \& Myers, R. R. (2003). The stages of a social problem. The study of Social Problems, 95103.

Harcup, T., \& O'neill, D. (2001). What is news? Galtung and Ruge revisited. Journalism studies, 2(2), 261-280.

Kaya, J. B. (2016). Representasi Homoseksual dalam Film The Imitation Game. Journal E- Komunikasi, $4,5-11$.

Khan, M. H., Adnan, H. M., Kaur, S., Khuhro, R. A., Asghar, R., \& Jabeen, S. (2019). Muslims' representation in Donald Trump's anti-muslim-islam statement: A critical discourse analysis. Religions, 10(2).

Maharani, P. (2018). Portraying the Multitudes: Representation of Ide ntities of Sexual Minorities on Indonesia-Based Feminist Web Magazine Magdalene.co. Journal of Southeast Asian Human Rights, 2(2), 358.

Metila, R. A. (2013). A Discourse Analysis of News Headlines: Diverse Framings for a Hostage-Taking Event.2(2), 71-78.

Muqqofa, M. (2020). The Jokowi's Ideology Reflected on the Annual Speech. Diglosia, 10 (1), 34-49.

Nisbet, R. A. (1971). Contemporary Social Problems. In 3rd. Harcout, Brace, Jovanovinch.

Nurhayati. (2014). Representasi Peristiwa dalam Media (Pemberitaan Banjir dalam Suara Merdeka). Parole, 4 no 2, 32-54.

Olson, D. ., \& M.Li. (2015). Does a Nation's Religious Composition Affect Generalized Trust? The Role of Heterogeneity and the Percent Religious. Religion, 4, 756-773.

Reynolds, C. (2019). Building Theory From Media Ideology: Coding for Power in Journalistic Discourse. Journal of Communication Inquiry, 43(1), 47-69.

Setiawan, K. A., Chojimah, N., \& Khasanah,I. (2018). Positive-Self and Negative-Other Representation in the Online News Behind Indonesia's Anti-Chinese Riots and Indonesia Turns Its Chinese into Scapegoats. Alphabet, 1(1), 57-68.

Tamburaka, A. (2016). Literasi Media; Cerdas Bermedia Khalayak Media Massa. Raja Pers.

Van Dijk, T. A. (1995). Ideology: A Multidisciplinary Approach. Sage.

Van Dijk, T. A. (2004). Ideology and Discourse. Pompeu Fabra University.

W.Moore, J. (2015). Capitalism in the Web of Life: Ecology and Accumulation ofCapital. Verso.

Wang, H., Tong, L., Takeuchi, R., \& George, G. (2016). Corporate social responsibility: An overview and new research directions. Academyof Management Journal, 59(2), 534-544. 
LiNGUA Vol. 15, No. 2, December 2020 • ISSN 1693-4725 • e-ISSN 2442-3823 